\title{
USING SYSTEMIC FUNCTIONAL GRAMMAR IN THE MEDIA CLASSROOM: INCREASING STUDENTS' ABILITY TO PRODUCE AND ANALYSE MEDIA TEXTS
}

Jenny Clarence-Fincham

University of Natal

This article explores the use of Systemic Functional Grammar in a module for University students entitled Analysing Media Texts. This module aims at assisting students to produce their own texts and to help them develop an understanding of the linguistic choices they make. Students are introduced to the key principles of CDA and to Halliday's SFG to provide them with tools to assist them to understand the social and constructed nature of discourses, especially those typically found in media texts. This article follows on (Clarence-Fincham 2000), which focuses on students' interpretation of media texts, their ability to read with greater understanding and to apply key concepts that they had learnt to their analyses. The students demonstrated clearly that they had developed an understanding of CDA, acquired the basic metalanguage necessary for Hallidayan analysis and some of them could produce much more rigorous textual analyses than before. This article focuses on the engagement and high level of motivation students showed when asked to produce their own texts. Examples of the texts are given of texts produced and analysed by the students. Students reported that choosing and constructing their own texts had been both beneficial and enjoyable. However, students were able to produce fine-tuned linguistic analysis in the time allotted-some of them still resorted to extremely mechanistic analyses which took no explicit account of the purpose or function of the language and still less of the significance of the linguistic choices made.

In hierdie artikel word die gebruik van sistemiese funksionele grammatika (SFG) in 'n universiteitsmodule Analysing Media Texts ondersoek. Die doel van die module is on studente te help om hulle eie tekste te produseer en die linguistiese keuses wat hulle maak te begryp. Studente word bekendgestel aan die sleutelbeginsels van Kritiese Diskoers Analise en aan Halliday se SFG as hulpmiddels by die begryp van die sosiale en gestruktureerde aard van diskoerse, veral dié wat eie is aan mediatekste. Hierdie artikel bou voort op (Clarence-Fincham 2000) se fokus op studente se interpretasie van mediatekste, hulle vermoë om met meer begrip te lees en hulle vermoë om die sleutelbegrippe wat hulle geleer het in hulle analises toe te pas. Die fokus is op die studente se betrokkenheid by en hulle hoë vlak van motivering teenoor die produksie van hulle eie tekste. Voorbeelde van studente se selfgeskrewe en geanaliseerde tekste word verskaf. Studente het gerapporteer dat die kies en konstrueer van hulle eie tekste sowel voordelig as genotvol was. Hulle was egter nie in staat om verfynde linguistiese analises te produseer in die toegelate tyd nie - party het selfs teruggeval op hoogs meganiese analises wat nie die doel of funksie van die taal en nog minder die betekenis van die linguistiese keuses in aanmerking geneem het nie. 


\section{INTRODUCTION}

The immediate pedagogical context for the work discussed here is a thirteen week, second level module in Applied Language Studies called Analysing Media Texts. This module links systemic functional grammar (SFG) and critical discourse analysis (CDA) to form a theoretical framework for the analysis and production of texts, drawn from newspapers, magazines and advertisements. Its broad aim is, in the context of Media Studies, to introduce students to the key principles of CDA and to Halliday's SFG as a system which is integrally related to social practice and to show how these can assist them to understand the social and constructed nature of discourses, especially those typically found in media texts.

The primary purpose of this article is to discuss one aspect of the course - the use of SFG as a means of assisting students to produce their own texts and, in doing so, to begin to understand and to analyse the importance of the linguistic choices they have made. Before focusing on this, however, I will begin with a brief introductory discussion of CDA, which, although not of central concern here, provides the critical dimension for the course as a whole, and, as such, is a crucial framework for the discussion which follows.

\section{THEORETICAL FRAMEWORK}

\section{Critical Discourse Analysis}

The broad theoretical framework for this course is CDA which is an approach to the study of discourse which attempts to explain how social inequalities are reflected and constructed in and through language and to find ways to challenge and to change these conditions of inequality (Pennycook, 1995). Its primary aim is to uncover and understand naturalised ideological representations which have come to be viewed as common-sense social practice and to elucidate and clarify the social effects of such practices. Practically, this means investigating verbal interactions with an eye to how they are shaped by, and how they shape, social structures (Fairclough, 1995c).

CDA revolves around the key concept of language as discourse or 'social practice' (Fairclough, 1989: 1), the idea that language practice is socially determined; it is a social act in itself which is in turn shaped by broader social and ideological conditions (Chouliaraki and Fairclough, 1999; Fairclough 1989, 1992, 1995; Fairclough and Wodak, 1997; Fiske, 1994; Gee, 1996; Kress, 1985; Mills, 1997; Pennycook, 1994, 1995; van Dijk, 1997). This notion of discourse challenges the possibility of autonomous subjects and ideologically neutral language use. Rather, human beings are viewed as socialised subjects whose subjectivities and language use are constructed within particular social and cultural discourses (Pennycook, 1995; Weedon 1997). Language, which always contains traces of its social history is what Fiske calls 'politicized, power-bearing language, employed to extend or defend the interests of its discursive community' (1994: 3). Discourses comprise complex, historically-based ways of constructing knowledge, social practices, subjectivity and the power relations which are implicit in these knowledges. Within this perspective, texts are viewed as social products and human subjects, because they have differential access to social, educational and political experiences, are differentially positioned in various social contexts. 
CDA is often associated with the work of Fairclough who argues, with Chouliaraki, that it should be seen, not as a particular theory but rather as 'one contributory element in research on social practices' (1999:16). Fairclough has developed a three dimensional model for CDA, $(1989,1992,1995 \mathrm{c})$ which comprises three interrelated domains, the descriptive, the interpretive and the explanatory.

The descriptive domain entails close textual and linguistic analysis involving both the traditional levels of analysis in terms of phonology, vocabulary, syntax and semantics and analysis of textual organisation in a broader sense which includes the sequencing of information and intersentential cohesion. Drawing on the work of Halliday $(1978$; 1985) Fairclough links this textual domain with ideational meaning which revolves around the way in which the world is represented.

The interpretive process is primarily concerned with the production and interpretation of texts as they emerge in specific social contexts. It is viewed as a dialectical interplay between various features of texts and what Fairclough terms 'members' resources' (1989: 11) which refer to socially constructed resources which are used by subjects to produce and interpret text.

The explanatory dimension foregrounds the relationship between the interaction between the productive and interpretive processes and the broad social context and represents discourse as a social practice which is shaped by social structures and which can sustain or change those structures (Fairclough, 1989). In understanding any text and the discourse of which it is part, the explanatory dimension explores which power relations, at situational, institutional and social levels contribute towards the shaping of the discourse.

\section{Systemic Functional Grammar}

While CDA provides the critical and ideological dimension to the analysis of texts, Halliday's SFG complements the critical perspective, providing linguists with fine-tuned insights into the social nature and function of particular linguistic systems. The two approaches have often been used in a complementary relationship (see, for example, groups in East Anglia and in Australia and also by Chouliaraki and Fairclough, 1999; Clark and Ivanic, 1997; Fairclough, 1992, 1995a and b; Janks, 1996; Kress, 1985) with CDA providing the critical edge that SFG lacks and SFG offering a powerful tool for detailed textual analysis. The remainder of this section will explain key Hallidayan concepts while the next will indicate how students were introduced to them.

As his point of departure, Halliday (1978: 4) argues that

language is as it is because of the functions it has evolved to serve in people's lives ... In order to understand linguistic structures in functional terms, we have to proceed from the outside inwards, interpreting language by reference to its place in the social process.

Briefly, Halliday argues that a language is interpreted as a system of meaning potential, accompanied by forms through which the meanings can be realised. He defines systemic theory as 'a theory of meaning as choice, by which a language, or any other semiotic system, is interpreted as networks of interlocking options' (1985: xiv). Functional linguistics, then, foregrounds linguistic choice and treats structures as derivable from the choices made via realisation rules: 'the relation between the semantics and the grammar is one of realisation: the word 'realises', or encodes, the meaning. The wording, in turn, is 'realised by' sound or writing 
(Halliday, 1985: xx). This concept of realisation enables Halliday to attempt an explanation of the relationship between text and context and to show how what he calls context of culture links to the immediate context of situation (the field, tenor and mode of discourse) and how this in turn is realised by the meta-functions of language (the ideational, the interpersonal and the textual) in the broader socio- historical context.

For Halliday, a text, in the broadest terms, is 'language that is functional' (Halliday and Hasan, 1989: 10), that is any language, written or spoken, which has social meaning in a particular, concrete, situation. Crucially, he views text as a semantic unit, an intersection of potential meanings, rather than a combination of words and sentences, and argues that it needs to be considered from two perspectives simultaneously, from the notion of text as product and of text as process. It is a product in that it is a linguistic structure which can be studied. At the same time it is a process 'in the sense of a continuous process of semantic choice, a movement through the network of meaning potential, with each set of choices constituting the environment for a further set' (Halliday and Hasan, 1989: 10). So a text is both structured and structuring; it draws on and exemplifies the linguistic system but is simultaneously located in specific and potentially new social contexts. It is 'an instance of social meaning in a particular context of situation' (Halliday and Hasan, 1989: 11). As such, all texts are 'channels for socially driven changes in the language system' (Chouliaraki and Fairclough, 1999: 141), and all texts open up the linguistic system to new contextual possibilities.

Halliday has developed a conceptual framework which he claims facilitates the understanding of the production and interpretation of text, and helps to capture the elusive relation between language and social structure. His point of departure is that the construction of a text is neither random nor mechanical, but is systematically related to both its social environment and the functional organisation of its language. A central question for him revolves around the ways in which individual texts interact with and relate to their social contexts.

Halliday begins by defining a text's outer framework or context of culture. This refers to the extralinguistic features of the text, the culturally-based conventions or 'the sum of all the meanings it is possible to mean in that particular culture' (Butt, 2000: 3). There is no explicit analysis of power relations here, but a consideration of cultural variables (which includes anything from religious affiliation and beliefs about gender relationships to gesture, intonation and modes of address) easily leads to such an analysis.

Within this broad context, Halliday places what he calls the context of situation. This is the immediate social context of a text which consists of three features which 'serve to interpret the social context of the text, the environment in which meanings are being exchanged' (Halliday and Hasan, 1989: 12). The first of these is the 'field of discourse' which refers to the type of social action being depicted in the text, what is going on. This social feature is realised at a linguistic/semantic level as the experiential metafunction, which involves an understanding of 'the processes being referred to, the participants in these processes, and the circumstances - time, cause, etc. associated with them' (Halliday and Hasan, 1989: 45). The central linguistic features which realise this function are lexicalisation, transitivity and voice.

The second feature of the context of situation is the 'tenor of discourse' which refers to the relationship between the participants in the text, their statuses and roles, the permanent or temporary nature of these relationships and the types of speech roles they are assuming in the 
dialogue. This also includes the speaker's/writer's attitudes towards the subject matter. Linguistically, it is realised as the interpersonal function of language and is characterised by systems of mood and modality in conjunction with lexical choice.

The third characteristic of the context of situation is the 'mode of discourse' which Halliday describes as referring to the function of the language of the text which includes its organisation, its channel and its status. For Halliday, the textual component has what he calls 'an enabling function' (1978: 113). It is only through the textual mode of discourse that ideational and interpersonal meanings are realised. The key linguistic features here are cohesion and coherence, and information structure. It is the combination of context of culture and context of situation which allows fruitful comparison between one text and another.

\section{Pedagogical Implementation}

In a previous article written about the development of the same course (Clarence-Fincham 2000), I focused on students' interpretation of media texts, on their ability to read with greater understanding and to apply key concepts that they had learnt to their analyses. Students demonstrated that they had developed an understanding of Fairclough's model for CDA, that they had acquired the basic metalanguage necessary for Hallidayan analysis and that some of them could produce much more rigorous, if rough-tuned, textual analyses than they had done previously. It was also clear that they were far more engaged when asked to produce their own texts than they were when asked to analyse existing text.

My observations on this engagement and the higher motivational levels form the focus of this article. During this module much more time was allocated to the production and analysis of student-generated texts. This was done in order to explore an aspect of the course which I felt was underdeveloped, to encourage students to reflect on what they were learning, to articulate the linguistic processes and choices involved and to make more explicit links with potential workplaces. This emphasis also meant that although the CDA was retained, less time was allocated to it and the interpretation of text.

The course began with an introduction to CDA. Using their own experience and texts drawn from newspapers and magazines, students generated questions which they considered necessary in order to analyse a text and were then introduced to various perspectives on discourse (Foucault, 1970; Kress, 1985; Mills, 1997; Fiske, 1994 and Fairclough, 1989, 1995a, 1995b) and to Fairclough's three dimensional model. They were also introduced to the central principles of critical linguistics. This was followed by a specific focus on media discourse which involved introducing students to ideas about genre (Bhatia, 1993), mythology, signs, text, intertextuality, anchorage, interpellation and ideology (Kress and van Leeuwen, 1996, Tolson, 1996).

Students were then introduced to key Hallidayan concepts including the relationship between grammar and meaning, the role of context, the social function of language and the importance of linguistic choice. Considerable time was spent analysing and constructing sentences in terms of lexical and grammatical choices and then considering the impact of alternative linguistic options, which in turn were linked to the power relations they represented. In fact, the concept of language as 'networks of interlocking options' (Halliday 1985: xiv), remained a central and controlling idea throughout, and one to which students returned on numerous occasions. They were then gradually introduced to the concepts of context of culture, context of situation, experiential, 
interpersonal and textual meaning and with each concept, a link to the Fairclough model was made. Context of culture, for example, was closely linked to the explanatory domain, but was not seen as synonymous with it. The situational components of situation of context and the linguistic realisations of each, were gradually introduced with field of discourse and experiential meaning linked to the descriptive domain, interpersonal meaning to the interpretative domain and textual meaning to all three.

\section{THE MAJOR ASSIGNMENT AND THE PRODUCTION OF TEXTS}

At the end of the second week, the students were given their major assignment in which they were required to produce three advertisements and, using insights from the course, to analyse and reflect on the processes and choices involved. It was introduced at this early stage so that the process of production could run for several weeks parallel with other aspects of the course and students could cycle and recycle their project through different stages as additional concepts were introduced.

Students were asked to create either a product of their own or to choose an existing product. Most opted to choose their own product, though one group chose to 're-brand' a Mercedes range. I also explained that it was the written text for the advertisement that was the focus of the task and that although visuals were welcome, students were not expected to produce sophisticated, computer generated texts.

In terms of the course design, this assignment entailed a scaffolded and detailed set of instructions and carefully timed practical classes during which students had the opportunity to reconsider their adverts in the light of new information and to deepen their analyses accordingly.

The completed project included a description of the overall production process, reasons for the choice of product, a description of the target audience, an indication of the discourses on which the adverts were based, problems encountered and changes made as a result of new linguistic insights. Concepts from media studies, most particularly myth, interpellation, anchorage and preferred reading were also included.

The adverts were then analysed in terms of their Context of Culture, Context of Situation, Experiential, Interpersonal and Textual meaning with special emphasis on why certain choices were made rather than others. The assignment ended with a personal reflection on the whole production process.

Students worked in groups of three or four, discussing, refining, arguing about the impact of various choices and modifying their adverts during an eight week period. At the end of the module, they did an oral presentation which was collectively assessed and they each then submitted a written account of the process which was individually assessed.

\section{Analysis of student texts}

The following extracts drawn directly from students' written assignments provide a flavour of the project as a whole. I have included examples of the more general descriptions of, for instance, field tenor and mode, of attempts to produce closer linguistic analyses, and of students' personal reflection on the process as a whole. 


\section{Text A}

The first text (see appendix A), is a two-page advert for a special life-changing deodorant called 'No name'. The student frames her analysis with some general observations beginning with an explanation of the relationship between the text and the visual:

On the first page the relationship between the text and the visual is vital. The text invokes an image in ones head even without there being an image linked to the text ... By providing an image we build on their [the readers] mental picture and possibly change it in some ways. The words work without the image but providing the image we are making sure that the reader reads it . . as we want them to. The image would work to a point without the text but the text ensures that the viewer reads the image in a certain way. So the text and the image build on and enhance one another...

She then moves to the discourses drawn upon to structure the advert and to a brief description of the field, tenor and mode:

The discourse that we are drawing on is that of unpopularity and aloneness. We chose this discourse, as it is one that most people can understand as most people have experienced what it is like to be unpopular and alone.

The field for this advertisement is that of popularity and friendship, we are working in the field of relationships and what it is like not to have the relationships that you would like to have. We are selling the readers values and a better lifestyle than they have at the moment.

The tenor is informal, relaxed and personal. The questions ask about very sensitive things that you would never ask someone unless you knew them very well ... it's almost as though the advertiser is playing the role of an intimate friend.

The language is used in the interrogative style; it is very direct and the questions almost come across as statements. The mood system is also very important when analysing the tenor of a text.

It is clear from these descriptions that she is well able to contextualise her analysis using concepts drawn from different aspects of the course. Furthermore, in her description of the mode of discourse, for example, she is also able to link situational features, if only briefly, to their linguistic realisations.

Her attempts to explain analytical process show that she is beginning to confront some of the more complex linguistic challenges of this task. She says:

In this advertisement we had difficulty analysing the sentences as they were not actually 'proper' sentences. To analyse them we expanded them into full sentences and we only used the part that we had originally written down. What this made us notice was that none of our sentences, as we were using them, had 
agents or subjects (depending on which domain we were analysing them in). This highlighted for us why we were using the sentences in their incomplete form, the reason being to make it sound like we were talking to any readerfeeling this way. The text on the second page of the ad is very different to that on the first and this is important, as is needs to come across strongly and with emphasis. The text on the first page is in the interrogative mood; it is questioning and 'feeling its way' while the text on the second page is confident and sure - it is in the declarative mood and makes a statement. On the second page, we first used a strong modal 'will' plus a Material Process 'makes', saying 'No Name will make others know your name' and then at the bottom of the page under the product we repeated the Material Process - 'It makes them know your name'.

Although I would have like to have seen a more detailed explication of how students retrieved and analysed the full propositional form of their sentences, here this does student that she is beginning to grapple with the precise effect of the use of one form over another, the impact of the agentless sentence on the meaning of the text as a whole. Her comparison of the interrogative and the declarative parts of the advert and her analysis of the modal 'will' in conjunction with the Material Process 'makes' also indicates a good grasp of key Hallidayan concepts and suggests the beginnings of a metalanguage to aid her reflection on the linguistic processes involved. This is corroborated further in her personal reflection as she writes:

I enjoyed the process ... although it was a lot of work, Ifelt that it was helpful to show us how what we had learnt in class was useful. . In the beginning we did not really look at why we ... had used the language that we had. It was only once we started to analyse the text in detail that we started to see what we had done and once we saw that all the sentences were agentless, we could understand how this changed our text to give the desired effect. From this point of view I found it really useful as it suddenly started to make a lot of sense as to how our language choices change and alter the entire meaning of the text and result in people reading differently. Before, we would have answered questions about why we chose the structure that we did with 'just because' - now we can explain why our choices were important and the effects that they have.

\section{Text B}

The second text (see Appendix A) advertises a university in the context of the new South Africa, 'The Freedom University' or the deliberately ambiguous FU for short.

Context of Culture: This ad is written for the SA context. It is produced after 1994 (after the elections) and is aimed at getting the attention of young people of the so called previously disadvantaged group.

The pictures in this ad are very important - they show how this university turns the old world upside down ... and the text supports that meaning. It is an anchor.

In his linguistic analysis, this student focused on Textual and Interpersonal meaning:

... the original copy of the ad contained too much of written text, so using the 
pattern of to-days ads, we had to minimize the written text. The structure of some sentences had to be changed to meet the aim of the advert. For example, sentence two was 'They had held you down for years.' In this sentence the attention is on the agent which is the Theme but our aim was to mark the time so we changed the sentence to 'For years, they have held you down' and the whole idea changes from agent to time. By putting Circumstance first, we used a marked topical theme instead of the unmarked Agent Theme. Sentence 3 is deliberately ambiguous - to some people it could mean rude language - it confirms the anger felt by some yet the whole idea is to introduce the institution. The final ad has undergone changes of about $60 \%$ from the original ...

The first two sentences are declarative mood sentences and we chose to do this to show the past events and the future events without doubt. However the last sentence is in the Imperative mood: it is a command 'come join us . . .' Our pronoun choice was also interesting - by choosing 'you' and 'they' we were able to separate the two groups and make them distant from each other.

It is clear from this, that he has grasped the role and importance of Theme in the text and has learnt to manipulate it and, more importantly, to explain how that manipulation shapes the meaning of the text and links directly with its overall aim. In addition, in his discussion of the interpersonal meaning, he is able to compare different moods and relate these to the social purpose of the text. Interestingly though, in other parts of his analysis he takes refuge, as several students did, in the safer, more mechanistic, grid type analysis in which each word is analysed in terms of each domain with no reference whatever to the importance of the linguistic choices made or to the social purpose of the text.

\section{Text C}

In technological terms, this text, with its accompanying visuals (see appendix A) was the most elaborate of the adverts and certainly one which generated an enormous amount of discussion, debate and disagreement. Students in this group really did negotiate each aspect of their text, from appropriate lexical choices and accompanying photographs to choice of Verbal Process and Mood. The chose an already existing product and adapted it according to their own purpose. The advert consisted of five related texts advertising Mercedes-Benz, each specifically designed to meet the requirements of a different social group which was represented by an attached photograph. One of the students described the Context of Culture of this advert as follows:

The ad is created in an environment that is experiencing a lot of change. Everyday there are new inventions and technology being made. This change comes with different styles that people have to adapt to. In the past MercedesBenz cars were seen as cars for rich and white people only. . . As the world changes with many transformations in our country we have more people of colour driving these cars although they get a glance now and then from those who think they might have stolen the cars... So in these ads we are trying to say it is $O K$ to drive these cars [no matter who you are] ... You don't have to be rich and boring. You can be funny, casual person and still enjoy this car. This is why we used a mixture of people in our ads because it shows that beliefs and values of 
people do different cultures change and people change with them. There is an emphasis on equality in our ads.

Student analysis of these adverts tended to focus on the Experiential meaning. One student described it as follows:

For the M-class we used words that are Material Processes such as 'cruise', 'drive', 'trek' and 'meet'. We did this because we wanted to portray lots of movement in the ad and also because the visual indicates lots of action and movement. We also did not include the agent because we felt that it have more effect and gives the message more clearly in this way. The text has only the Process and the Goal. In the other ads, the C-class for example, we used attributive relational processes to relate the participants to the description of the car. An example of this is 'You're cool', 'you still appreciate'. We included the carrier here because we are focusing on what the participants are like. Participants are part of the Interpersonal meaning.

Another provided a slightly different emphasis, providing more insight into the choice process involved:

... We had thought of using the verbs in their participle form-cruising driving trekking - but decided against it. Instead, we used the verbs in their active imperative form and made sure that all the Processes were Material Processes. The Verbal Groups are commanding the reader to cruise, drive and trek as is there is no other option once you own the Mercedes M-class. The commands also seem militaristic as they are agentless - this emphasises the masculinity of the car . . we could have said 'Now you can ...' at the beginning of each line but this would have detracted from the commanding nature of the text.

She then links this to the construction of the reader:

The preferred reader here is a man but the fact the woman is included in the photograph means that the woman could also be part of the preferred readership. In each advert, the photo directly interpellates the preferred reader but the range of readers is increased by the text describing the car. The nature of this and the other adverts is such that even if you are not the preferred reader, the advert makes it desirable to become a preferred reader.

In both these cases, the students illustrate a clear understanding of how experiential meaning is functioning within the text with the first one attempting to show the difference between Material and Attributive Relational Processes.

\section{CONCLUSION}

Several general conclusions can be drawn from these analyses. Comments from all the students confirmed that choosing and constructing their own texts had been both beneficial and enjoyable. When they are able to produce their own meaning instead of trying to interpret someone else's, 
they can find a focus and work within their range of abilities. At the same time, the group work often results in students moving beyond existing knowledge to new linguistic insights. Several of the students developed sufficient metalanguage to explain and to analyse the linguistic processes involved in the production of text. In addition, there was far more frequent and explicit reference to the social nature and purpose of texts

These observations, however, should be tempered by equally strong evidence that, in the allocated time, students were not able to produce anything that might be classified a fine-tuned linguistic analysis and indeed, some of them still resorted to extremely mechanistic analyses which took no explicit account of the purpose or function of the language and still less of the significance of the linguistic choices made.

In all cases though, this process required students to engage closely with the texts in question and to make a conscious effort to link what they had learnt in class to the challenges of an ongoing, practical task. As on student said 'I'll never write anything again without thinking about why I have written this way rather than that.'

My experience of teaching this material over a number of years has led me to conclude that the terminology involved in Hallidayan grammar is potentially no more of a hindrance than any other grammatical terminology. As with any set of grammatical terms, there is no question that their acquisition is a complex process and that some students do this better than others. As these student analyses have shown, systemic functional grammar, within a critical framework, has the potential to facilitate the development of critical response to text that takes account both of its structure and its social construction. Student feedback supports this view. A remark from one of the students sums up the feelings of the majority.

Personally I found using SFG very interesting. It has made me capable of reading any text critically and not just to accept anything I read without questioning why something is written as it is. It was very confusing at first because there is a lot of terminology but now I understand a lot better. I like knowing how important choices are and how they change meaning. The grammar we did at school wasn't like that - I could never see the point of it at all.

\section{REFERENCES}

BHATIA, VJ. 1993. Analysing genre: Language use in professional settings. London: Longman.

BUTT, DR FAHEY, S SPINKS \& C YALLOP. 2000. Using functional grammar: An explorer's guide. Macquarie University: Clarendon Printing.

CARTER, R (ed.). 1990. Knowledge about language and the curriculum: The LINC reader. London: Hodder and Stoughton.

CHOULIARAKI, L AND N FAIRCLOUGH. 1999. Discourse in late modernity: rethinking critical discourse analysis. Edinburgh: Edinburgh University Press. 
CLARENCE-FINCHAM, JA 2000. Understanding text as social practice: an exploration of the potential of systemic functional grammar to facilitate students' interpretation of media texts. Per Linguam 16(2): 14-30

FAIRCLOUGH, N. 1989. Language and power. London: Longman.

FAIRCLOUGH, N. 1995a. Media discourse. Cambridge: Polity Press.

FAIRCLOUGH, N. 1995b. Critical discourse analysis: The critical study of language. London: Longman.

FAIRCLOUGH, N. 1995c. Language and social change. Cambridge: Polity Press.

FAIRCLOUGH, N. AND WODAK, R. 1997. 'Critical discourse analysis'. in van Dijk, T. A. ed. 1997. Discourse as social interaction. London: Sage Publications. pp. 258-284.

FISKE, J. 1994. Media matters: Everyday culture and political change. Minneapolis: University of Minnesota Press.

FOUCAULT, M. 1970. The order of Discourse. In Young, R (ed.), Untying the text: A poststructuralist reader. London: Routledge and Kegan Paul: 48-78.

FOWLER, R, HODGE B, KRESS G, AND TREW, T. 1979. Language and control. London: Routledge and Kegan Paul.

GEE, JP. 1996. Social linguistics and literacies: ideology in discourses. Second edition. London: The Falmer Press.

HALLIDAY, MAK. 1978. Language as social semiotic: the social interpretation of language and meaning. London: Edward Arnold.

HALLIDAY, MAK. 1985. An introduction to functional grammar. London: Edward Arnold.

HALLIDAY, MAK AND R HASAN. 1989. Language, context and text: Aspects of language in a social-semiotic perspective. Second Edition. Oxford: Oxford University Press.

IVANIC, R. 1990. Critical language awareness in action. In Carter, R (ed.), Knowledge about language and the curriculum: The LINC reader. London: Hodder and Stoughton. pp. 122-133.

JANKS, H. 1996. 1996: Why we still need critical language awareness in South Africa. Paper presented at the third Stellenbosch Conference on Linguistics for the Language Professions.

KRESS, G. 1985. Linguistic processes in sociocultural practice. Oxford: Oxford University Press.

KRESS, G AND T VAN LEEUWEN. 1996. Reading images: The grammar of visual design. 
London: Routledge

MILLS, S. 1997. Discourse. London: Routledge.

PENNYCOOK, A. 1994. The cultural politics of English as an international language. London: Longman.

PENNYCOOK, A. 1995. Incommensurable discourses? Applied linguistics, 15(2): 115-138.

TAYLOR, L. AND A WILLIS. 1999. Media studies: Texts, institutions and audiences. Massachusetts: Blackwell

TOLSON, A. 1996. Mediations: Text and discourse in media studies. London: Arnold.

VAN DIJK, TA. 1997. Discourse as interaction in society. In van Dijk, TA (ed.), Discourse as social interaction. London: Sage Publications

VAN DIJK, TA (ed.). 1997. Discourse as social interaction. London: Sage Publications.

WEEDON, C. 1997. Feminist practice and poststructuralist theory. Second Edition. Oxford: Basil Blackwell.

\section{Biographic Note}

Jenny Clarence-Fincham teaches in the School of Language, Culture and Communication at the Universtiy of Natal, Pietermaritzburg. (email: Clarence@nu.ac.za). 
Appendix A

\section{Text A}

Feeling lonely?

In need of a social life?

No friends?

Feeling unpopular?

Wish they knew you name?

One spray of No Name will

make others

know your name!!

NO NAME

Makes them know your name

\section{Text B}

They have given you people's education

For years they have held you down

What two words come to mind?

FU!

Freedom univerisity for people with vision

Come join us, 5000 people can't be wrong!

\section{Text C}

Cruise Mozambique to Morocco ...

Drive Melville to the Malutis ...

Trek Mom to the Mall

Meet the most macho Mercedes

The new M-class

You're cool with modern communications

but you till appreciate the classic comfort

the characterises the new

Mercedes C-class 